\begin{tabular}{ll} 
Bentham open & The Open Dentistry Journal \\
\hline CrossMark & Content list available at: www.benthamopen.com/TODENTJ/ \\
\hline
\end{tabular}

CASE REPORT

\title{
Parotid Gland Edema After Chlorhexidine Mouthrinse: Case Report and Literature Review
}

\author{
Federico Berton ${ }^{1}$, Giulia Pipinato ${ }^{1}$, Michele Maglione ${ }^{1}$, Domenico Baldi ${ }^{2}$, Roberto Di Lenarda ${ }^{1}$ and \\ Claudio Stacchi, \\ ${ }^{I}$ Department of Medical, Surgical and Health Sciences, University of Trieste, Trieste, Italy \\ ${ }^{2}$ Department of Surgical Sciences, University of Genova, Genova, Italy
}

Received: November 7, 2018

Revised: December 5, 2018

Accepted: December 21, 2018

Abstract:

\section{Introduction:}

Parotid gland swelling, caused by many pathological conditions, has also been reported to be a possible side effect of the use of chlorhexidine mouthwash. This adverse reaction to chlorhexidine mouthwash is, however, extremely rare and very few cases of parotid gland swelling due to chlorhexidine mouthwash have been reported in the literature.

\section{Case Description:}

This report describes the clinical management of unilateral parotid swelling caused by chlorhexidine mouthwash.

\section{Methods:}

A patient presented with left parotid gland swelling after using chlorhexidine mouthwash for three days following sinus augmentation on the contralateral side of the maxilla. Diagnosis of parotid gland swelling due to rinsing with chlorhexidine was formulated after anamnesis, clinical examination, radiographs and ultrasound of the gland excluded other pathological conditions. The patient was subsequently advised to stop rinsing. However, on the evening of the same day, swelling increased and the patient presented to an emergency department where a single intravenous dose of methylprednisolone was administered.

\section{Results:}

After seven days, parotid swelling decreased significantly and after three weeks had completely disappeared.

\section{Conclusion:}

Although unilateral or bilateral parotid gland swelling related to the use of chlorhexidine mouthwash is an uncommon adverse event, it must be suspected after other organic or infective conditions have been excluded. The precise pathogenic mechanism has not yet been determined and further studies should be carried out to better understand the pathophysiology of this uncommon phenomenon.

Keywords: Chlorhexidine, Parotid gland swelling, Mouthwash, Ultrasound, Masseteric hypertrophy, Piezoelectric antrostomy.

\section{INTRODUCTION}

Numerous conditions causing swelling of the parotid gland are known including: masseteric hypertrophy due to constant clenching, bruxism or gum chewing; sialadenosis (alcoholism, endocrine disorders, eating disorders); bacterial or viral infections (acute suppurative parotitis, epidemic parotitis, HIV); autoimmune diseases (Sjögren syndrome);

\footnotetext{
"Address correspondence to this author at the Dental School, Department of Medical, Surgical and Health Sciences, University of Trieste, Piazza dell’Ospitale 1, 34129 Trieste, Italy; Tel + (39) 0403992563; Fax: + (39) 0403992193; E-mail: claudio@stacchi.it
} 
granulomatous diseases such as Wegener granulomatosis or sarcoidosis; congenital diseases (polycystic parotid disease); induced diseases (pneumoparotid, anesthesia or radioactive iodine sialadenitis); neoplastic diseases (Warthin tumor); direct trauma and sialolithiasis $[1,2]$.

Unilateral or bilateral parotid gland swelling is also a reported side effect of chlorhexidine mouthwash [3]. Chlorhexidine, a bis-biguanide cationic antiseptic active against Gram-positive and Gram-negative bacteria, has been widely used in medical practice since its introduction in 1954 as an antiseptic cream and has been successfully used in dentistry since the 1970s and considered the gold standard for antimicrobial mouthwashes [4].

Parotid gland swelling after chlorhexidine mouthwashes is an uncommon adverse reaction. Its estimated incidence among patients who regularly use this product is less than $1.0 \%$ [5]. This condition resolves spontaneously within a few days after suspending use of the mouthwash [5]. To date, six cases of parotid gland swelling due to use of $0.12 \%$ chlorhexidine mouthwash have been reported in the scientific literature and only one case due to use of a different mouthwash containing $0.1 \%$ hexetidine (a saturated pyrimidine derivative cationic antiseptic) $[5,6]$ (Table 1).

Table 1. Cases of parotid gland edema following antiseptic mouthwash reported in literature.

\begin{tabular}{|c|c|c|c|c|c|c|c|c|c|c|}
\hline Reference & $\begin{array}{c}\text { Year of } \\
\text { Publication }\end{array}$ & Gender & Age & $\begin{array}{c}\text { General } \\
\text { Comorbidities }\end{array}$ & Mouthrinse & Indication & Dosage & $\begin{array}{l}\text { Onset } \\
\text { Time }\end{array}$ & Treatment & Resolution \\
\hline $\begin{array}{l}\text { McCoy LC } \\
\text { et al. }\end{array}$ & 2008 & NR & NR & $\begin{array}{c}\text { Poorly controlled } \\
\text { diabetes }\end{array}$ & $\begin{array}{c}0,12 \% \\
\text { chlorhexidine }\end{array}$ & $\begin{array}{l}\text { Periodontal } \\
\text { therapy }\end{array}$ & BID & NR & NR & NR \\
\hline $\begin{array}{l}\text { McCoy LC } \\
\text { et al. }\end{array}$ & 2008 & NR & NR & $\begin{array}{c}\text { Poorly controlled } \\
\text { diabetes }\end{array}$ & $\begin{array}{c}0,12 \% \\
\text { chlorhexidine }\end{array}$ & $\begin{array}{c}\text { Periodontal } \\
\text { therapy }\end{array}$ & BID & NR & NR & NR \\
\hline $\begin{array}{c}\text { McCoy LC } \\
\text { et al. }\end{array}$ & 2008 & NR & NR & $\begin{array}{l}\text { Poorly controlled } \\
\text { diabetes }\end{array}$ & $\begin{array}{c}0,12 \% \\
\text { chlorhexidine }\end{array}$ & $\begin{array}{c}\text { Periodontal } \\
\text { therapy }\end{array}$ & BID & NR & NR & NR \\
\hline $\begin{array}{l}\text { McCoy LC } \\
\text { et al. }\end{array}$ & 2008 & NR & NR & $\begin{array}{c}\text { Poorly controlled } \\
\text { diabetes }\end{array}$ & $\begin{array}{c}0,12 \% \\
\text { chlorhexidine }\end{array}$ & $\begin{array}{c}\text { Periodontal } \\
\text { therapy }\end{array}$ & BID & NR & NR & NR \\
\hline $\begin{array}{c}\text { McCoy LC } \\
\text { et al. }\end{array}$ & 2008 & NR & NR & $\begin{array}{c}\text { Poorly controlled } \\
\text { diabetes }\end{array}$ & $\begin{array}{c}0,12 \% \\
\text { chlorhexidine }\end{array}$ & $\begin{array}{c}\text { Periodontal } \\
\text { therapy }\end{array}$ & BID & NR & NR & NR \\
\hline $\begin{array}{c}\text { Van der } \\
\text { Weijden GA } \\
\text { et al. }\end{array}$ & 2010 & M & 59 & None & $\begin{array}{c}0,12 \% \\
\text { chlorhexidine }\end{array}$ & Post-surgical & BID & 4 days & Discontinuation & NR \\
\hline $\begin{array}{c}\text { Van der } \\
\text { Weijden GA } \\
\text { et al. }\end{array}$ & 2010 & $\mathrm{~F}$ & 21 & None & $0.1 \%$ hexetidine & $\begin{array}{c}\text { Periodontal } \\
\text { therapy }\end{array}$ & BID & $\begin{array}{c}1.5 \\
\text { days }\end{array}$ & $\begin{array}{l}\text { Discontinuation }+ \\
\text { sour sweets }\end{array}$ & 2 weeks \\
\hline Berton et al. & 2018 & M & 66 & None & $\begin{array}{c}0,2 \% \\
\text { chlorhexidine }\end{array}$ & Post-surgical & TID & 3 days & $\begin{array}{c}\text { Discontinuation }+ \\
\text { corticosteroids }\end{array}$ & 7 days \\
\hline
\end{tabular}

Abbreviations: $\mathrm{NR}=$ not reported; $\mathrm{BID}=$ twice per day; $\mathrm{TID}=$ three times per day

\section{CASE DESCRIPTION}

The patient, a healthy 66-year-old Caucasian male, underwent maxillary sinus augmentation with lateral approach on the right side in an outpatient procedure under local anesthesia with piezoelectric antrostomy as described elsewhere $[7,8]$. The patient was prescribed amoxicillin-clavulanate $(875+125 \mathrm{mg}$ twice a day for 5 days $)$ in combination with metronidazole ( $250 \mathrm{mg}$ three times a day for 5 days). As part of postoperative care, the patient was instructed to rinse with $0.2 \%$ chlorhexidine mouthwash three times a day for one week until suture removal. After only three days, the patient presented at our clinic, reporting sudden swelling of the left cheek (Fig. 1).

The patient underwent thorough clinical and instrumental examination. Swelling was evident in the left parotid region with no sign of inflammation (redness, fever, or pain) and in absence of any other symptom. All teeth on the left side were asymptomatic, with no sign of acute inflammation or infection. Clear saliva flowed from the Stenone duct after squeeze maneuvers on the left parotid gland. A panoramic radiograph and ultrasound examination of the gland were performed to exclude other pathological conditions, confirming the presence of edema and hyperemia of the gland (characterized by increased blood flow revealed by colour Doppler ultrasound, (Fig. 2)), with no other organic alteration. Therefore, a diagnosis of parotid gland swelling due to chlorhexidine rinsing was formulated. The patient was advised to stop rinsing immediately and his condition was monitored over the following days. On the evening of the same day swelling increased and the patient presented at an emergency department where a single dose of intravenous methylprednisolone $(40 \mathrm{mg})$ was administered, without suspending antibiotic therapy. The patient had never previously experienced similar adverse events. 


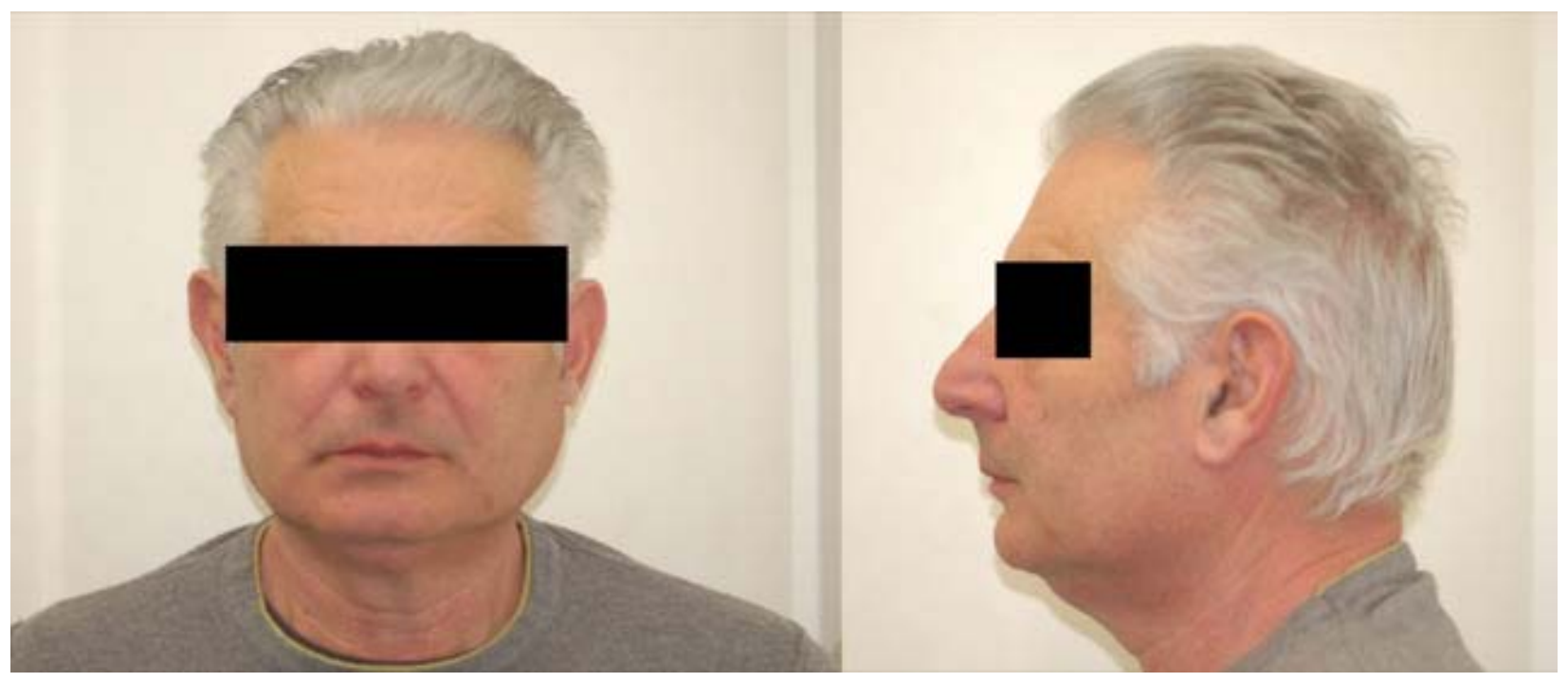

Fig. (1). Unilateral parotid swelling on the left side (frontal and sagittal view).

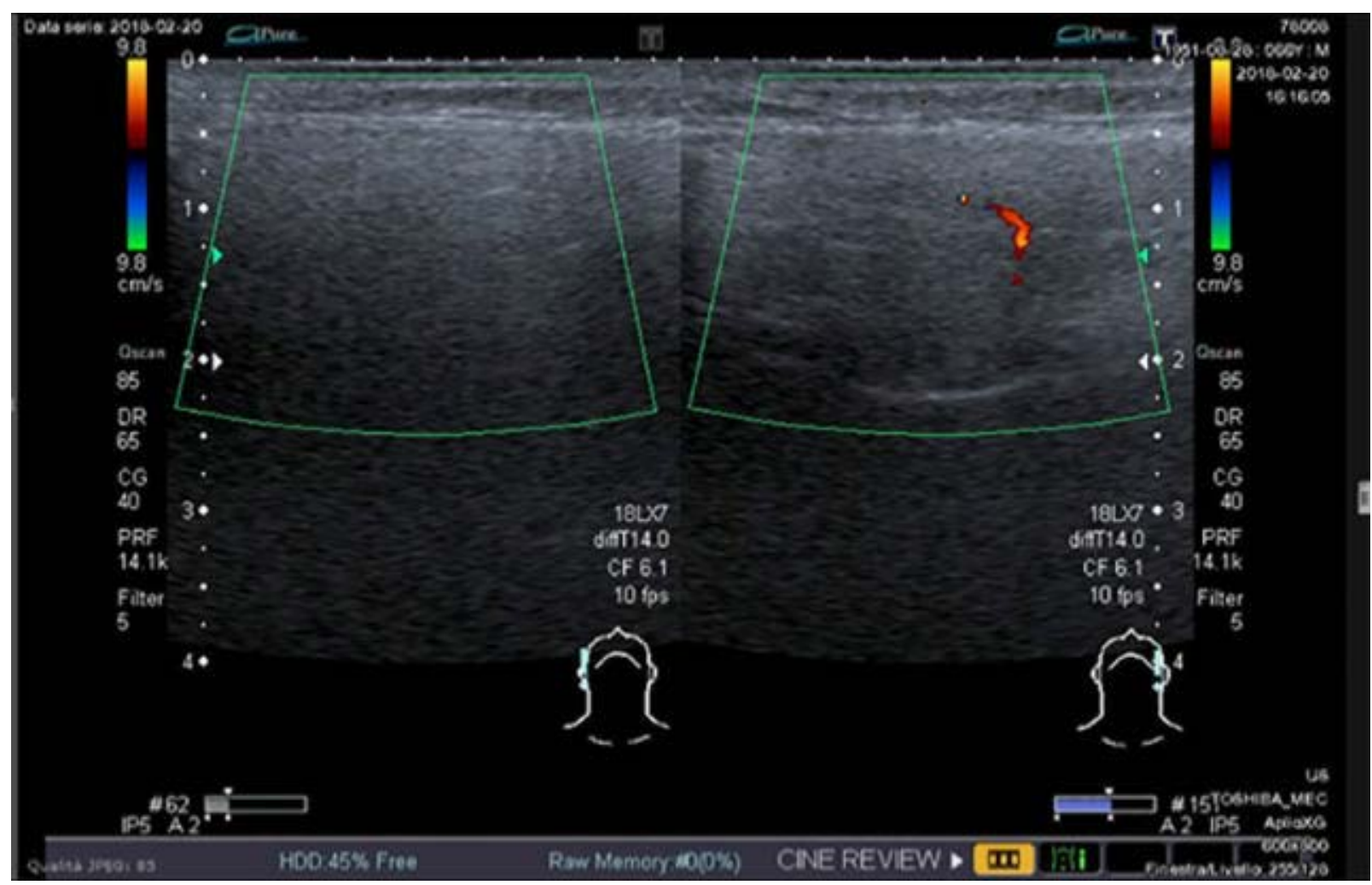

Fig. (2). Comparative ultrasound evaluation of the parotid gland, appearing inhomogeneously edematous on the left, with minimal increase in vascularization, in a reactive/phlogistic pattern.

After seven days, at suture removal, parotid swelling had decreased significantly and the patient reported no other signs or symptoms. Healing of the surgical wound (contralateral side) was uneventful.

Three weeks later, the patient presented at the follow-up appointment with no sign of swelling and complete remission of symptoms. 


\section{DISCUSSION}

This case report describes an apparent correlation between unilateral parotid gland swelling and chlorhexidine mouthwash.

In differential diagnosis, infective etiology was excluded due to the administration of broad-spectrum antibiotic therapy and absence of typical signs of inflammation or infection such as pain, fever or altered salivary flow (in either quantity or quality).-The allergic reaction was excluded due to delayed onset of swelling and its unilateral localization. No salivary duct stones or masses were found and all diagnostic tests resulted negative. No trauma was reported by the patient and iatrogenic etiology related to the recent surgery (pneumoparotid, anesthesia) was excluded as sinus augmentation was performed on the opposite side. No bad habits (alcoholism, eating disorders, bruxism or gum chewing) were referred and all other possible diseases were excluded after analysis of the patient's medical history.

The pathogenetic mechanism by which chlorhexidine causes parotid swelling still remains unclear. It has been suggested that vigorous rinsing may cause mechanical obstruction of the parotid duct and predispose individuals to unilateral or bilateral parotid swelling and inflammation (sialadenitis). This hypothesis is supported by swelling remission after recommending gentler or cessation of rinsing [9]. An alternative consideration suggesting a mechanical cause is that parotid gland swelling has been reported after use of chlorhexidine mouthwash, but not after other methods of chlorhexidine administration. How this obstruction occurs, is still under debate. Vigorous rinsing may cause the mouthwash to enter the parotid duct with consequent inflammatory reaction and edema, causing narrowing of the lumen and a transient obstruction [9].

An alternative explanation is that chlorhexidine may reduce natural resistance of the mucous membranes to viral infection. Bacteriostatic effect of this mouthwash and its precipitating action on salivary mucins covering the oral mucosa reduces the bacterial load and may alter the oral environment [4]. However, parotid gland swelling in this case report arose after three days of chlorhexidine use which is too short a treatment period to cause deep alterations of the oral environment. Therefore, parotid swelling following the use of chlorhexidine mouthwash here described is possibly the result of the rinsing procedure itself. A complete explanation, however, remains unavailable.

\section{CONCLUSION}

Parotid gland swelling, although very uncommon, is a possible side effect of chlorhexidine mouthwash when other organic or infective conditions have been excluded. The correct clinical and instrumental examination should be performed in order to evaluate every possible pathological condition related to parotid swelling. Even if the pathophysiological mechanism has still not yet been clearly determined, the patient showed a good response to corticosteroid administration. Parotid gland edema as a side effect of chlorhexidine mouthwash should be considered in the differential diagnosis of acute swelling of the parotid gland and in appropriate preventive and therapeutic strategy.

\section{ETHICS APPROVAL AND CONSENT TO PARTICIPATE}

Not applicable

\section{HUMAN AND ANIMAL RIGHTS}

No animals/humans were used for studies that are the basis of this study.

\section{CONSENT FOR PUBLICATION}

Informed consent was obtained from the patient prior to being enrolled in the study.

\section{CONFLICT OF INTEREST}

The authors declare no conflict of interest, financial or otherwise.

\section{ACKNOWLEDGEMENT}

The Authors wish to acknowledge Dr. Gabriele Bazzocchi for the execution and interpretation of ultrasound examination.

\section{REFERENCES}


[http://dx.doi.org/10.1067/moe.2002.121163] [PMID: 11925529]

[2] Neville BW, Damm DD, Allen CM, Chi AC. Oral and maxillofacial pathology. $4^{\text {th }}$ ed. Saint Louis: Elsevier 2016.

[3] Addy M, Moran J. Clinical periodontology and implant dentistry. Oxford: Blackwell Munksgaard 2008; pp. 744-65.

[4] Flötra L, Gjermo P, Rölla G, Waerhaug J. Side effects of chlorhexidine mouth washes. Scand J Dent Res 1971; 79(2): 119-25. [PMID: 5280246]

[5] Van der Weijden GA, Ten Heggeler JM, Slot DE, Rosema NA, Van der Velden U. Parotid gland swelling following mouthrinse use. Int J Dent Hyg 2010; 8(4): 276-9 [http://dx.doi.org/10.1111/j.1601-5037.2009.00419.x] [PMID: 20961383]

[6] McCoy LC, Wehler CJ, Rich SE, Garcia RI, Miller DR, Jones JA. Adverse events associated with chlorhexidine use: results from the Department of Veterans Affairs Dental Diabetes Study. J Am Dent Assoc 2008; 139(2): 178-83. [http://dx.doi.org/10.14219/jada.archive.2008.0134] [PMID: 18245686]

[7] Stacchi C, Vercellotti T, Toschetti A, Speroni S, Salgarello S, Di Lenarda R. Intraoperative complications during sinus floor elevation using two different ultrasonic approaches: A two-center, randomized, controlled clinical trial. Clin Implant Dent Relat Res 2015; 17(Suppl. 1): e117-25. [http://dx.doi.org/10.1111/cid.12136] [PMID: 23968289]

[8] Stacchi C, Lombardi T, Cusimano P, et al. Bone scrapers versus piezoelectric surgery in the lateral antrostomy for sinus floor elevation. J Craniofac Surg 2017; 28(5): 1191-6.

[http://dx.doi.org/10.1097/SCS.0000000000003636] [PMID: 28538071]

[9] Rushton A. Safety of hibitane. II. Human experience. J Clin Periodontol 1977; 4(5): 73-9. [http://dx.doi.org/10.1111/j.1600-051X.1977.tb00053.x] [PMID: 275279]

(C) 2018 Berton et al.

This is an open access article distributed under the terms of the Creative Commons Attribution 4.0 International Public License (CC-BY 4.0), a copy of which is available at: https://creativecommons.org/licenses/by/4.0/legalcode. This license permits unrestricted use, distribution, and reproduction in any medium, provided the original author and source are credited. 